\title{
Acknowledgement to Editors and Scientific Referees 2021
}

To whom correspondence should be addressed: Matheus Fernando Manzolli Ballestero, $\mathrm{MD}, \mathrm{PhD}$

e-mail: ballestero@gmail.com

Available at:

http://www.archpedneurosurg.com.br/
A scientific journal's greatest responsibility is to ensure that all contributions accepted for publications are rigorously but fairly reviewed. The Editor-in-Chief and Archives of Pediatric Neurosurgery gratefully acknowledge the qualified and regular collaboration of renowned medical doctors and scientists who kindly devoted their time to constructively review the submitted articles. Their expertise and invaluable assistance contributed to maintain a high scientific standard for APN. We are thus indebted to the Editorial Board members and the following experts who reviewed papers and completed the peer-reviewing process within 2021.
Alexandre Canheu

Alexandre Varella Giannetti

Aline Saré

Amanda Lopez

Angelo Silva Neto

Carlos Eduardo Barros Jucá

Daniel Cardeal

Guilherme Podolsky-Gondim

\section{Gustavo Sampaio}

Jaqueline Garcia de Almeida

Ballestero

José Aloysio da Costa Val Filho

José Roberto Tude

Juan Salas

Leopoldo Mandic Furtado

Linoel Valsechi 
Luciano Furlanetti

Marcelo Volpon Santos

Marco Tulio Rezende

Marcos Devanir Silva da Costa

Matheus Ballestero

Nelci Zanon

Patricia Dastoli

Paulo Ronaldo Jubé Ribeiro
Ricardo Gepp

Ricardo Santos de Oliveira|

Roberto Alexandre Dezena

Sergio Cavalheiro

Simone Rogério

Tatiana Protzenko

Vinícius Marques Carneiro 